\title{
Nickel and cobalt adsorption on hydroxyapatite: a study for the de-metalation of electronic industrial wastewaters
}

\author{
Michele Ferri $\cdot$ Sebastiano Campisi $\cdot$ Antonella Gervasini \\ Dipartimento di Chimica, Università degli Studi di Milano, via Camillo Golgi 19, \\ 20133 Milano, Italy
}

AUTHORS' INFORMATION

Corresponding Author

*E-mail: antonella.gervasini@unimi.it

ORCID

Michele Ferri: 0000-0002-3862-6709

Sebastiano Campisi: 0000-0002-5496-7482

Antonella Gervasini: 0000-0001-6525-7948 


\begin{abstract}
In the present study, the $\mathrm{Ni}$ (II) and $\mathrm{Co}(\mathrm{II})$ adsorption efficiency and selectivity, as well adsorption mechanisms on a stoichiometric hydroxyapatite (HAP) surface have been investigated. Characterization studies ( $\mathrm{N}_{2}$ adsorption/desorption and X-ray powder diffraction (XRPD) analyses) and adsorption tests under various operative conditions provided detailed information about the use of HAP in the de-metalation of wastewaters containing Ni and Co as polluted metal species. The sorption capacity of HAP has been evaluated by static batch adsorption tests varying initial concentration of $\mathrm{Ni}(\mathrm{II})$ and $\mathrm{Co}(\mathrm{II})$ species (from ca. 0.25 to $4.3 \mathrm{mM}$ ), contact time (from $15 \mathrm{~min}$ to $24 \mathrm{~h}$ ), and $\mathrm{pH}$ (from 4 and 9) operative parameters. Proposed mechanisms of adsorption of $\mathrm{Ni}(\mathrm{II})$ and Co(II) on HAP surface are ion-exchange and surface complexation; a partial contribution of chemical precipitation from bulk solution should be considered at $\mathrm{pH}$ 9. In addition, adsorption isotherms of $\mathrm{Ni}(\mathrm{II})$ and $\mathrm{Co}(\mathrm{II})$ on $\mathrm{HAP}$ have been collected at $30^{\circ} \mathrm{C}$ and $\mathrm{pH} 4$ and modeled by employing different equations. The maximum sorption capacities have been quantified as $0.317 \mathrm{mmol} \mathrm{g}^{-1} \mathrm{HAP}\left(18.6 \mathrm{mg} \mathrm{g}^{-}\right.$ $\left.{ }_{\mathrm{HAP}}\right)$ and $0.382 \mathrm{mmol} \mathrm{g}^{-1} \mathrm{HAP}\left(22.5 \mathrm{mg} \mathrm{g}^{-1} \mathrm{HAP}\right)$ for $\mathrm{Ni}(\mathrm{II})$ and $\mathrm{Co}(\mathrm{II})$, respectively. Selectivity to Co and $\mathrm{Ni}$ in the adsorption process on HAP has also been investigated; HAP has higher affinity towards Co than Ni species (Co: $\mathrm{Ni}=2.5: 1$, molar ratio).
\end{abstract}

Keywords: hydroxyapatite; Co and Ni polluting species; adsorption isotherms; surface complexation. 
Graphical Abstract

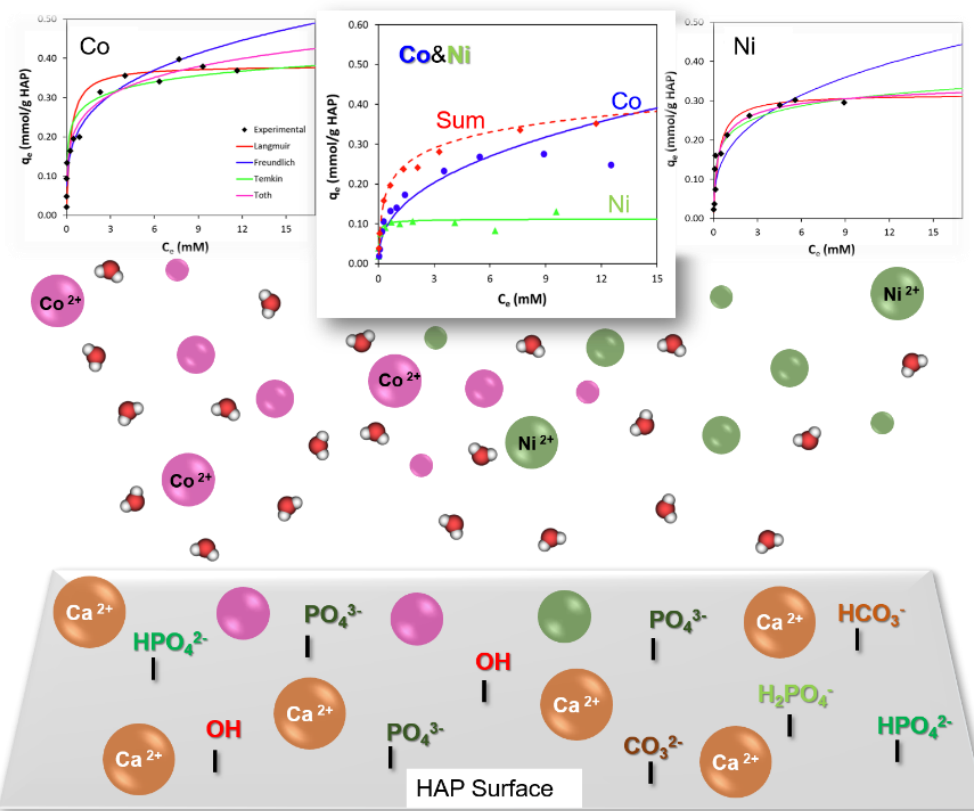




\section{Introduction}

Due to their well-known toxicity towards both plants, animals and humans (Singh et al. 2011b), heavy metals concentration in water is subject to a strict legislation, with limit contents down to the range of ppb for particularly hazardous species (WHO 2017).

The major contribution to heavy metal species presence in waterbodies is ascribable to industrial effluents (e.g. electronic and batteries industries, steelmaking, dyes production, metal-based catalytic processes, among others), therefore attention should be paid to those technology fields which are experimenting a rapid market growth, associated with an enhanced waste throughput.

With the global spreading of portable electronic devices, the automotive market moving towards electric power and the consequent demand for more performant and high-power density batteries, the industry of electrical energy storage is exploring new solutions. From the well-established nickel metal hydride batteries, $\mathrm{NiMH}$ (Fetcenko et al. 2007), to the promising $\mathrm{LiNi}_{0.8} \mathrm{Co}_{0.2} \mathrm{O}_{2}$ cathodes for high-power lithium ion-cells (Chen et al. 2004), nickel and cobalt proved through the years to be fundamental for the development of a future based on electrical power. In virtue of their forecasted larger use in electrical devices manufacture and the future creation of processes dedicated to spent batteries/cathodes recycling (Rabah et al. 2008), Ni(II) and Co(II) can be addressed as the "future" wastewater pollutants.

At present time, nickel compounds are known as carcinogenic to humans and animals; cobalt compound are carcinogenic to animals and probably to humans, too. Mechanism of action of these compounds are under study but evidences of chemical damage to DNA in presence of these metals and free oxygen radicals have been found (Nackerdien et al. 1991). Actually, Ni(II) upper limit in drinking water is set at $20 \mu \mathrm{g} / \mathrm{L}$ (WHO 2017). Co(II) limits are not clearly defined since it is a micronutrient: its concentration in fresh and drinking water is nowadays negligible respect to the mean human Co(II) uptake from foods, which are its main source of absorption (Howe and Kingdom 2006). 
Nowadays, $\mathrm{Ni}$ (II) and $\mathrm{Co}(\mathrm{II})$ removal from wastewaters is achieved by chemical precipitation at basic pH (using different methods and reagents for alkalinization) (Dean et al. 1972; Rötting et al. 2006), but even by more environmental friendly methods, such as phytomining (Chaney et. al. 1998), adsorption (Corami et al. 2008; Ma et al. 1994; Reichert and Binner 1996) and gene engineered bacteria (Singh et al. 2011a), the latter still under lab scale experimentation.

Among all the methods that have been proposed and developed, simple adsorption presents several advantages (flexibility, low operational cost, and easiness of industrial application/scaling), especially when realized on effective, low cost and naturally available sorbents (Babel and Kurniawan 2003; Bailey et al. 1999).

Hydroxyapatite (HAP, $\left.\mathrm{Ca}_{10}\left(\mathrm{PO}_{4}\right)_{6}(\mathrm{OH})_{2}\right)$ is the most stable compound of the calcium phosphates family (Meyer, J.L. Eanes 1978). HAP is the principal constituent of hard tissues of all mammals, it is a low-cost material, largely available in nature (Liss and Slater 1974) and biocompatible (RiveraMunoz 2011). HAP is characterized by good thermal and chemical stability (Meejoo et al. 2006), marked insolubility in water $\left(\mathrm{K}_{\mathrm{ps}} \approx 4 \cdot 10^{-59}\right)$, even in moderate acidic environment (Recillas et al. 2012, Ferri et al. 2018) and ability to immobilize heavy metal cations in aqueous phase (Ma et al. 1994; Reichert and Binner 1996; Skwarek and Janusz 2016) thanks to $\mathrm{Ca}^{2+}$ exchange properties. The ion exchange capability of HAP derives from its peculiar structural flexibility which allows to replace framework Ca-ions (both $\mathrm{Ca}(\mathrm{I})$ and $\mathrm{Ca}(\mathrm{II})$ of the framework) with different ions (not only bivalent ions) without any distortion. In addition, HAP exhibits different acid and basic sites at its surface, which have been extensively exploited even in the field of heterogeneous catalysis, both as bare material (Fihri et al. 2017) and metal-loaded support (Campisi et al. 2019; Schiavoni et al. 2018). In fact, the amphoteric nature of HAP surface has been recognized and quantification of acid/basic sites has been performed by titration in liquids (acid site titration with phenylethylamine in cyclohexane and water or basic site titration with benzoic acid, (Ferri et al. 2018) and in gas phase ( $\mathrm{NH}_{3}-\mathrm{TPD}$ and $\mathrm{CO}_{2}$-TPD, (Silvester et al. 2014)). 
Consequently, structural flexibility together with surface acid properties are responsible for the fact that heavy metal species trapped by HAP can occur with different mechanisms; the principals being ion exchange, surface complexation, and dissolution/precipitation (Campisi et al. 2018; Flores-Cano et al. 2016; Mousa et al. 2016; Pham Minh et al. 2013). The occurrence of a given adsorption mechanism depends on the nature of the metal species and operative conditions (Smičiklas et al. 2009). The concomitance of many adsorption mechanisms allows to address and control the uptake processes when several metal species are present (Chen et al. 2010). Moreover, the extreme heterogeneous nature of HAP surface represents an additional feature which is often neglected or regarded as complexity element, whereas it can be properly exploited to tailor the selectivity towards specific metal species. Indeed, HAP presents at least three different surface species suitable for cations adsorption on its surface: hydroxyl-, carbonate- and phosphate-groups. Previous studies reported that these sites can interact with variable strength with different cations, depending on the specific combination metal ion-active site (Campisi et al. 2018).

$\mathrm{Ni}(\mathrm{II})$ and $\mathrm{Co}(\mathrm{II})$ uptake on HAP or on biochar has been studied extensively as single metal ions (Janusz and Skwarek 2018; Mobasherpour et al. 2012; Mobasherpour et al. 2011; Rosskopfová et al. 2013; Smičiklas et al. 2006), however, to the best of our knowledge competitive effects between these two metal species have not been reported in the literature.

With the perspective of an increasing amount of $\mathrm{Ni}(\mathrm{II})$ and $\mathrm{Co}(\mathrm{II})$-based electronics and the expected co-presence of these pollutants in industrial wastewaters, this study would like to draw attention to this possible future environmental issue. For this purpose, both the quantification of the uptake ability of synthetic HAP and the understanding of the competitive effects between the two metal ions are here investigated for the first time. Comprehension of the phenomena, fundamental for the correct treatment of polluted wastewaters, can be achieved only with collection of adsorption isotherms of the single metal and binary solutions. To investigate HAP trapping ability and the influence of operational parameters, static batch tests were carried out under isothermal conditions $\left(30^{\circ} \mathrm{C}\right)$, at different initial metal concentrations (from ca. 0.25 to $c a .4 .2 \mathrm{mM}$ ), $\mathrm{pH}$ (4 and 9) and with different 
contact times (from 15 minutes to 24 hours) for single metal solutions. Then, adsorption isotherms on HAP have been collected for both the single metal ions and binary $\mathrm{Ni}$ (II) and $\mathrm{Co}$ (II) containing solutions. Then, the obtained adsorption isotherms have been fitted according to several adsorption equation models, to discover the surface mechanism involved on the adsorption process. The experimental evidences and their interpretation can help in designing tailored sorbents with enhanced adsorption efficiency towards $\mathrm{Ni}(\mathrm{II})$ and $\mathrm{Co}(\mathrm{II})$, which can be useful tools for approaching future environmental challenges.

\section{Experimental Setup and Methods}

\subsection{Materials}

Calcium nitrate tetrahydrate, $\mathrm{Ca}\left(\mathrm{NO}_{3}\right)_{2} \cdot 4 \mathrm{H}_{2} \mathrm{O}$ ( $>99.0 \%$, from Merck ACS) and diammonium hydrogen phosphate, $\left(\mathrm{NH}_{4}\right)_{2} \mathrm{HPO}_{4} \quad(>98.0 \%$, from Sigma-Aldrich) were used to prepare stoichiometric HAP in aqueous solution; 28-30 \% in weight of ammonium hydroxide solution, $\mathrm{NH}_{4} \mathrm{OH}\left(28-30 \%\right.$ from Fluka) was used to adjust $\mathrm{pH}$ of the $\left(\mathrm{NH}_{4}\right)_{2} \mathrm{HPO}_{4}$ starting solution to $\mathrm{pH} 10$ and to maintain it during the $\mathrm{Ca}\left(\mathrm{NO}_{3}\right)_{2} \cdot 4 \mathrm{H}_{2} \mathrm{O}$ addition.

$\mathrm{Ni}\left(\mathrm{NO}_{3}\right)_{2} \cdot 6 \mathrm{H}_{2} \mathrm{O}\left(>99.0 \%\right.$ from Sigma-Aldrich) and $\mathrm{Co}\left(\mathrm{NO}_{3}\right)_{2} \cdot 6 \mathrm{H}_{2} \mathrm{O}(>99.0 \%$ from Merck) were used as sources of $\mathrm{Ni}$ (II) and $\mathrm{Co}$ (II) ions, respectively, for the tests of heavy metal uptake. All the aqueous solutions were prepared by using MilliQ water (15.0 M $\Omega$, Millipore). The $\mathrm{pH}$ value of initial solutions was corrected by addition of $\mathrm{HNO}_{3}$ or $\mathrm{NaOH} 0.5 \mathrm{M}$.

\subsection{Synthesis of HAP}

Stoichiometric HAP was synthetized following a co-precipitation route as reported elsewhere (Campisi et al. 2018; Lamonier et al. 2011). Briefly summarizing, the synthesis consisted in a dropwise addition of a $\mathrm{Ca}\left(\mathrm{NO}_{3}\right)_{2} \cdot 4 \mathrm{H}_{2} \mathrm{O}$ aqueous solution to a $\left(\mathrm{NH}_{4}\right)_{2} \mathrm{HPO}_{4}$ solution. Precursors concentrations and volumes were calculated as to achieve a stochiometric $\mathrm{Ca} / \mathrm{P}$ ratio (ca. 1.67). Throughout the synthesis, suspension has been kept under mechanical stirring $(200 \mathrm{RPM})$ at $80^{\circ} \mathrm{C}$; 
$\mathrm{pH}$ value of $c a .10$ was maintained by periodic additions of $28-30 \% \mathrm{NH}_{4} \mathrm{OH}$ solution. Once the addition was terminated, the suspension was hot-filtered and thoroughly washed with hot water until neutrality of the rinsing water. Obtained HAP was then dried and thermal treated according to standard procedures (Campisi et al. 2018, Ferri et al. 2018).

\subsection{Structural and Morphological Characterization of HAP}

The nitrogen adsorption-desorption isotherms were obtained at $77 \mathrm{~K}$, using a Sorptomatic 1990 version instrument from Thermo Scientific (Carlo Erba). The analysis was controlled by computer processing using the MILES-200 program and the MILEADP software for computations. The adsorption branch of the isotherm $\left(0.005<\mathrm{p} / \mathrm{p}^{0}<0.4\right)$ has been modeled by the 3 -parameter BET equation for the determination of the specific surface area. The desorption isotherm has been interpreted using the B.J.H. (Barrett-Joyner-Halenda) model $\left(0.3<\mathrm{p} / \mathrm{p}^{0}<0.95\right)$, thus determining the pore size distribution of the samples in the mesopores region. Prior to the analysis, $c a .150 \mathrm{mg}$ of sample (previously dried at $120^{\circ} \mathrm{C}$ overnight), were outgassed for $4 \mathrm{~h}$ at $150^{\circ} \mathrm{C}$ under high vacuum to free all pores from moisture. Nitrogen used for the analyses was $99.9995 \%$ purity. To convert adsorbed volume $\left(\mathrm{cm}^{3}(\mathrm{STP}) \cdot \mathrm{g}^{-1}\right)$ into pore volume $\left(\mathrm{cm}^{3} \cdot \mathrm{g}^{-1}\right), \mathrm{N}_{2}$ density in normal liquid state and molecular area of $\mathrm{N}_{2}$, was taken as $0.8081 \mathrm{~g} \cdot \mathrm{cm}^{-3}$ and $0.162 \mathrm{~nm}^{2}$, respectively.

Routine XRPD analyses on powder samples were performed using a Philips Powder X-ray diffractometer equipped with a PW 1830 generator, monochromator in graphite, with $\mathrm{Cu} \mathrm{K \alpha}(\lambda=$ $0.15418 \mathrm{~nm}$ ) radiation. The X-ray tube operated at $40 \mathrm{kV} \times 40 \mathrm{~mA}$. Diffraction patterns were registered

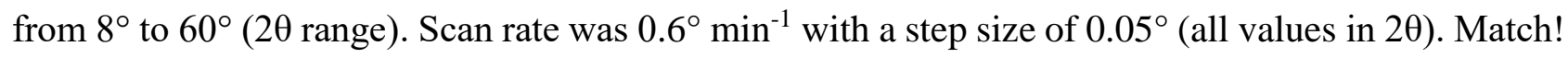
Software, from Crystal Impact GbR was used for the identification of crystal phases in the obtained patterns. Unit cell refinement was performed using CelRef V3 software (developed at Laboratoire des Matériaux et du Génie Physique, Ecole Nationale Supérieure de Physique de Grenoble).

\subsection{Adsorption Tests and Isotherms}


Batch adsorption experiments of $\mathrm{Ni}(\mathrm{II})$ and $\mathrm{Co}(\mathrm{II})$ have been performed in static condition; the tests were carried out in test tubes placed in a thermostatic bath at $30^{\circ} \mathrm{C}\left( \pm 0.1^{\circ} \mathrm{C}\right)$. This selected is close to the operative temperature used in several aerobic biological treatment plants (Corbala-Robles et al. 2016). In a typical experiment, $10 \mathrm{~mL}$ of $\mathrm{Ni}(\mathrm{II})$ or $\mathrm{Co}(\mathrm{II})$ solution were statically contacted with ca. $0.1 \mathrm{~g}$ of HAP powder, thus yielding a solid to solution ratio of $c a$. 1:100. Initial solution concentrations ranged from $c a .0 .25 \mathrm{mM}$ to $c a .4 .2 \mathrm{mM}$ (corresponding to $c a .15-250 \mathrm{ppm}$ ), for both $\mathrm{Ni}(\mathrm{II})$ and $\mathrm{Co}(\mathrm{II})$. At given time intervals (15 minutes, $8 \mathrm{~h}$, and $24 \mathrm{~h}$ ), the supernatant was collected, diluted as necessary, and analyzed by ICP-AES (Perkin-Elmer, Optical Emission Spectrofotometer, Model Optima 8000 DV). Nickel and cobalt standard solutions $\left(1,000 \mu \mathrm{g} / \mathrm{mL}, 2 \% \mathrm{HNO}_{3}\right.$ from Perkin Elmer) were used for ICP-AES calibrations. Static adsorption tests were performed at $\mathrm{pH}$ value of both 4 and 9, adjusting the $\mathrm{pH}$ with dropwise addition of $\mathrm{HNO}_{3}$ and $\mathrm{NaOH} 0.5 \mathrm{M}$ respectively. Isotherms of $\mathrm{Ni}(\mathrm{II})$ and $\mathrm{Co}(\mathrm{II})$ adsorption were collected with an experimental setup similar to the batch adsorption experiments (test tubes in thermostatic bath at $30^{\circ} \mathrm{C}\left( \pm 0.1^{\circ} \mathrm{C}\right)$, solid to solution ratio ca. 1:100), in this case the tests were conducted under vigorous stirring. Typically, $10 \mathrm{~mL}$ of 12 initial solutions, containing $\mathrm{Ni}(\mathrm{II})$ or $\mathrm{Co}(\mathrm{II})$ in concentrations ranging from $c a .0 .25 \mathrm{mM}$ to $c a .20 \mathrm{mM}$ (corresponding to $c a$. 15-1200 ppm), were added to a weighted amount of HAP (ca. $0.1 \mathrm{~g})$ in thermostated glass test tubes. Initial $\mathrm{pH}$ of the initial solutions was fixed at $\mathrm{pH} 4$ by $\mathrm{HNO}_{3}(0.5 \mathrm{M})$ addition. The equilibrium was considered reached after $2 \mathrm{~h}$ contact (Mobasherpour et al. 2012). Adsorption isotherms of $\mathrm{Ni}(\mathrm{II})$ and $\mathrm{Co}(\mathrm{II})$ co-present in solution were collected by preparing solutions with an equal molar amount of both the metallic species at the same concentrations used for the collection of the single adsorption isotherm, thus doubling the initial total metal concentration respect to single metal experiments. For all experiments, stirring was stopped after $2 \mathrm{~h}$ contact and the supernatant was collected by syringe suction, avoiding solids dragging by means of nylon syringe filters (purchased from Axiva, filtration rating $0.45 \mu \mathrm{m}$ ). Supernatant were then treated as previously described to be analyzed by ICP-AES. 
Equilibrium data obtained from the collected adsorption isotherms were then fitted according to Langmuir, Freundlich, Temkin, Toth, and Flory-Huggins model isotherms. The equations applied in the present study, also in their linearized form, could be found in the S.I.

\section{Results and Discussion}

\subsection{HAP Characterization}

The composition, structure, and morphology of synthetic HAP sample have been characterized by ICP-AES analyses of the mineralized sample, XRPD, and $\mathrm{N}_{2}$ adsorption/desorption analysis, respectively. The prepared HAP sample was a stoichiometric calcium hydroxyapatite; the $\mathrm{Ca} / \mathrm{P}$ molar ratio, was 1.689 (Table 1), close to the expected 1.67 value.

Fig. 1a shows the isotherm of $\mathrm{N}_{2}$ adsorption/desorption obtained on HAP sample: a typical hysteresis in the desorption branch was detected (type IV isotherm, according to IUPAC classification). This suggests that the obtained HAP was a mesoporous material, as further confirmed by the measured mean pore radius $(5.2 \mathrm{~nm})$ and pore size distribution (Fig. S1) centered in the range of mesoporosity (Table1). Surface area, calculated by means of 3-parameters B.E.T. equation on the low-pressure region of the adsorption branch of the isotherm, resulted to be slightly higher than $100 \mathrm{~m}^{2} \mathrm{~g}^{-1}$ (Table 1). The modeling of both B.E.T. and B.J.H. methods on the isotherm are reported in Fig. S1. The results of compositional and morphological features, presented in Table 1, are in good accordance with those reported in previous articles (Campisi et al. 2018, Ferri et al. 2018), confirming the reproducibility of our employed synthetic route.

Fig. $1 \mathrm{~b}$ shows the X-ray powder diffraction (XRPD) pattern of synthetic HAP (black line). From the analysis of the lines, it resulted that the only crystalline phase present in the sample was hydroxyapatite with an average crystallite sizes of $c a .56 \times 9 \mathrm{~nm}$, evaluated by Scherrer equation (Table S1), in accordance with TEM images reported in previous studies (Ferri et al. 2018). The same study has revealed that HAP obtained by the employed co-precipitation method could reach $99.9 \%$ 
crystallinity, arranging in a nano-needle like structure without any amorphous phases as verified by Rietveld refinement.

\subsection{Static Batch Adsorption Tests}

As a first step, the sorption capability of HAP towards Ni(II) and $\mathrm{Co}(\mathrm{II})$ ions has been investigated by batch adsorption tests in static conditions. Effects of initial concentration of both $\mathrm{Ni}$ (II) and $\mathrm{Co}$ (II) (from $c a .0 .25$ to $c a .4 .2 \mathrm{mM}$ ), $\mathrm{pH}$ value, and contact time (from 15 minutes to $24 \mathrm{~h}$ ) have been evaluated. The main results obtained are represented) in Fig. 2a and Fig. 3a as percentage removal of $\mathrm{Ni}(\mathrm{II})$ and $\mathrm{Co}(\mathrm{II})$, respectively; Table 2 presents the metallic uptake amounts onto HAP (expressed in in mmol $\left._{\mathrm{Me}} \mathrm{g}_{\mathrm{HAP}}{ }^{-1}\right)$.

At $\mathrm{pH} 4$, whatever was the initial $\mathrm{Ni}(\mathrm{II})$ and $\mathrm{Co}(\mathrm{II})$ concentration in the solutions (Fig.s $2 \mathrm{a}$ and $3 \mathrm{a}$, yellow bars), the adsorption processes resulted to be strongly affected by the contact time. Actually, the longer the contact time and the higher the initial metal concentration, the higher was the final measured metal uptake onto HAP (maximum values achieved 0.132 and $0.165 \mathrm{mmol}_{\mathrm{HAP}}{ }^{-1}$ for Ni(II) and $\mathrm{Co}(\mathrm{II})$ respectively, at $24 \mathrm{~h}$ contact time and initial metal concentration ca. $4.2 \mathrm{mM}$, Table 2). A strong effect of the contact time on the HAP adsorption efficiency was expected as, under static conditions, mass transfer kinetics are known to play a major role on adsorption processes, as also observed in a previous study realized in our laboratories dealing with $\mathrm{Cr}$ (III) adsorption on HAP (Ferri et al. 2018). When adsorption tests are carried out in the same initial metal concentration range but under dynamic conditions (vigorous stirring, contact time of $2 \mathrm{~h}$ ), the measured percent uptake of $\mathrm{Ni}(\mathrm{II})$ and $\mathrm{Co}(\mathrm{II})$ was higher than $90 \%$ (at initial concentration of $c a .0 .2 \mathrm{mM}$ and ca. $1.1 \mathrm{mM}$ ) and higher than $60 \%$ (at initial concentration ca. $4.2 \mathrm{mM}$ ). Thus, the observed limited adsorption of Ni(II) and $\mathrm{Co}$ (II) onto HAP under static conditions did not correspond to saturation of HAP towards Ni(II) and $\mathrm{Co}(\mathrm{II})$ adsorption but, more probably, the adsorption was limited from mass transfer and electrostatic limitations. Moreover, at pH 4, HAP surface exhibits a partial positive charge (Smičiklas et al. 2000) $\left(\mathrm{pH}_{\mathrm{PZC}} \approx 6\right.$ (Smičiklas et al. 2006)), therefore, repulsive electrostatic interactions might rise between the heavy metal cations and HAP surface when $\mathrm{pH}<\mathrm{pH}$ PZC. Cations adsorption onto a 
positively charged surface is however possible (Medellin-Castillo et al. 2017), with a mechanism of ion-exchange with the cations present on the sorbent surface (in the case of $\mathrm{HAP}, \mathrm{H}^{+}$and $\mathrm{Ca}^{2+}$ ), in particular for long contact time.

Regarding the adsorption mechanisms, the most loaded Ni(II)/HAP and Co(II)/HAPs samples (in terms of mmol $\mathrm{gHAP}^{-1}$ ), have been analyzed by XRPD; the corresponding diffraction patterns are reported in Fig. $1 b$ (red and green curves, respectively).

The absence of new peaks or shift of the diffraction lines of HAP allows ruling out the formation of new phases containing $\mathrm{Co}$ or $\mathrm{Ni}$ and/or of distortion of HAP unit cell (Table S2) due to $\mathrm{Co}$ (II) or $\mathrm{Ni}(\mathrm{II})$ insertion in the lattice. Moreover, the average crystallite size, calculated for $\mathrm{Ni}(\mathrm{II})$ and $\mathrm{Co}(\mathrm{II})$ loaded HAP samples, did not strongly differ from bare HAP (Table S1). Based on these evidences, the predominant adsorption mechanism, for both metal species, should correspond to surface complexation.

Literature reporting the efficiency of $\mathrm{Ni}(\mathrm{II})$ and $\mathrm{Co}(\mathrm{II})$ removal from water solutions in the presence of other solid sorbents under comparable conditions is limited. Modified clinoptiloite (a mineral belonging to the family of natural zeolites) has been reported to immobilize lower amounts of both

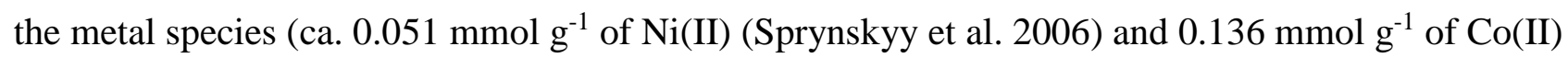
(Chmielewskà-Horvthovà and Lesny 1992)), respectively.

When $\mathrm{Ni}(\mathrm{II})$ and $\mathrm{Co}(\mathrm{I})$ adsorption was performed at $\mathrm{pH}$, percent removal of $\mathrm{Ni}(\mathrm{II})$ and $\mathrm{Co}(\mathrm{II})$ reached values higher than $90 \%$ in most cases, independently of contact rime and initial metal concentration. At this $\mathrm{pH}$ value, overcoming the $\mathrm{pH}_{\mathrm{PZC}}$ of HAP, the observed marked increase of $\mathrm{Ni}(\mathrm{II})$ and $\mathrm{Co}(\mathrm{II})$ uptake on HAP surface (>96\% after $24 \mathrm{~h}$ for both metal species) is due to a favored electrostatic adsorbate-adsorbent interaction, together with an expected chemical precipitation of both the $\mathrm{Co}(\mathrm{II})$ and $\mathrm{Ni}$ (II) species from bulk solution (as reported in $\mathrm{Ni}(\mathrm{II})$ and $\mathrm{Co}$ (II) speciation graphics in Fig. $2 b$ and $3 b$ ). Concerning the wastewaters de-pollution of heavy metallic species in alkaline conditions, literature presents several precipitation and co-precipitation methods approaching $100 \%$ efficiency for both Ni(II) (McAnally et al. 1984) and Co(II) (Rötting et al. 2006). 


\subsection{Adsorption Isotherms}

\subsubsection{Single metal adsorption isotherms}

To gain knowledge on the thermodynamics of the adsorption process of $\mathrm{Ni}(\mathrm{II})$ and $\mathrm{Co}(\mathrm{II})$ species onto HAP surface and on the selectivity of the phenomena when $\mathrm{Ni}(\mathrm{II})$ and $\mathrm{Co}$ (II) are co-present in solution, adsorption isotherms of the single metal species and of the bimetallic pool have been collected at $30^{\circ} \mathrm{C}$ as reported in paragraph 2.4. Single metal $\mathrm{Ni}$ (II) and $\mathrm{Co}$ (II) experimental data were fitted according to several adsorption isotherm models, as reported in Fig. 4. As expected, the experimental points describe a curve asymptotically approaching a limiting value. A clear " $k n e e$ " is detectable in the range $1-3 \mathrm{mM}$, in terms of $\mathrm{Ni}(\mathrm{II})$ and $\mathrm{Co}(\mathrm{II})$ equilibrium concentration, before reaching a well clear plateau, indicating the saturation of the adsorption capacity of HAP surface. These isotherms curves could be well fitted by the Langmuir model (Table 3).

Actually, Langmuir isotherm is the simplest model for describing adsorption phenomena at solidfluid interface. Among the assumptions (described in the detail in S.I, paragraph S1), this model postulates the homogeneity of the sorbent surface (or at least of the adsorption sites towards a given adsorbate), a condition that HAP does not fulfill. The site homogeneity assumption of the Langmuir model does not reflect the extreme complexity of HAP surface, where different functional groups (phosphates, hydroxides, carbonates) are present and can bind metal species with a different relative interaction strength. Notwithstanding, Langmuir adsorption isotherm is useful and generally applied to several heterogeneous surfaces because it allows an estimation of parameters with important physical meaning, namely $\mathrm{n}_{\max }$, the total amount of adsorption sites present at the adsorbent surface. In any case, both $\mathrm{Ni}(\mathrm{II})$ and $\mathrm{Co}(\mathrm{II})$ adsorption data resulted to be satisfactory fitted by Langmuir equation; Table 3 reports the computed $\mathrm{n}_{\max }$ values: 0.317 and $0.382 \mathrm{mmol}_{\mathrm{HAP}^{-1}}$ for $\mathrm{Ni}(\mathrm{II})$ and Co(II), respectively. The higher amount of adsorption for Co(II) suggests a higher affinity of this species towards the HAP adsorption sites in respect to $\mathrm{Ni}(\mathrm{II})$, as already observed in the static batch adsorption tests (Fig. 2a and Fig. 3a). This hypothesis could be supported by the comparison of the 
values of the $b_{\text {ads }}$ parameters (Langmuir adsorption constant), which are indicative of adsorbatesorbent interaction strength. The $b_{\text {ads }}$ value is higher for $\mathrm{Co}(\mathrm{II})$ than for $\mathrm{Ni}(\mathrm{II})$, suggesting that electrostatic interaction and consequent bond between Co)II) and HAP adsorption sites are stronger than those of $\mathrm{Ni}(\mathrm{II})$.

To overcome the well-known limitations of Langmuir model and take into account the central role of surface heterogeneity on a complex surface as hydroxyapatite, other model adsorption isotherms have been explored. Freundlich isotherm equation is an alternative model commonly applied in modeling the adsorption processes on heterogenous surfaces (Anoop Krishnan et al. 2011; Benzaoui et al. 2018; Mohammad et al. 2017; Zhu et al. 2008). Specifically, Freundlich isotherm postulates an exponential distribution of the adsorption sites energy. In general, Freundlich model resulted to be less suitable than Langmuir in fitting the experimental data. However, the affinity trend of the metal ions with HAP was confirmed, resulting that HAP surface is more affine to $\mathrm{Co}(\mathrm{II})$ as suggested by the higher $\mathrm{K}_{\mathrm{F}}$ (Freundlich adsorption capacity) value for Co(II) than for Ni(II), reported in Table 3.

Toth isotherm, an empirical modification of Langmuir model, was also applied to the adsorption data. An exponential $\mathrm{n}$ parameter is embedded in this modified Langmuir equation, which value correlates to the heterogeneity of the surface (as described in paragraph $S 1$, for $n=1$ the sorbent surface is considered homogeneous, and Toth isotherm reduces to Langmuir equation). Differently from Freundlich model, Toth model hypotheses an energy distribution with a broadening at low energies, i.e. the number of low-energy sites is sensitively greater than the number of high-energy ones. Toth parameters were obtained fixing $\mathrm{n}_{\max }$ value as obtained from Langmuir equation and using non-linear regression tool of Excel Solver. The values of the Toth isotherm constant (n), reported in Table 3, resulted to be lower than 1 for both metal species, confirming HAP surface to be markedly heterogeneous in terms of adsorption sites type and strength, as previous study demonstrated (Campisi et al. 2018; Silvester et al. 2014).

Another important aspect to be considered in the adsorption processes is the role of lateral interactions. With the aim to take into account this phenomenon, Temkin model isotherm was also 
applied, since lateral interaction between adsorbate ions should not be negligible in the adsorption processes under study. Temkin equation fitted slightly worse than Langmuir one. From the regression, parameters correlated to the thermodynamics of $\mathrm{Ni}(\mathrm{II})$ and $\mathrm{Co}(\mathrm{II})$ adsorption could be obtained. The B parameter values (Table 3), linked to the $\Delta \mathrm{H}$ of the process (Ayawei et al. 2017), disclose a similar heat of sorption for the two metal species, according with the literature (Gupta et al. 2012). Differently, Temkin isotherm equilibrium binding constant $\left(\mathrm{A}_{\mathrm{T}}\right)$ differs almost of an order of magnitude between the $\mathrm{Ni}$ (II) and $\mathrm{Co}(\mathrm{II})$ species, indicating a stronger binding for $\mathrm{Co}$ (II) respect to $\mathrm{Ni}(\mathrm{II})$. This conclusion is in agreement with the results of $\mathrm{Ni}(\mathrm{II}) / \mathrm{HAP}$ leaching tests (release up to $12 \%$ of total $\mathrm{Ni}(\mathrm{II})$ present on HAP, Ferri et al. 2018); and concerning Co(II)/HAP, it was reported a fully keeping of the Co species on HAP when leaching tested are carried out in the same conditions (Smičiklas et al. 2006).

Finally, also the Flory-Huggins model was applied for the description of $\mathrm{Ni}(\mathrm{II})$ and $\mathrm{Co}(\mathrm{II})$ adsorption, to gain detailed knowledge on the spontaneity of the adsorption process, as explained in S1paragraph (Adsorption Isotherms). From the regressed $\mathrm{K}_{\mathrm{FH}}$ values, $\Delta \mathrm{G}^{0}$ of $\mathrm{Ni}(\mathrm{II})$ and $\mathrm{Co}(\mathrm{II})$ adsorption processes could be calculated (Table 3). The lower $\Delta \mathrm{G}^{0}$ value for $\mathrm{Co}(\mathrm{II})$ adsorption process confirms all the previous results, indicating the latter has more affinity to HAP surface than Ni(II) species.

The experimental data fitting of all the adsorption isotherm models applied in the linearized form are reported in Fig. S2 and S3.

In general, it was shown that Langmuir and Temkin are good models to describe Ni(II) and Co(II) adsorption phenomena. However, when considering heterogeneity of HAP surface and energy distribution of adsorption sites, other models emerged as suitable for the studied metal ions adsorption process. In particular, $\mathrm{Ni}(\mathrm{II})$ adsorption isotherm resulted to be well fitted by Toth equation (Table 3), suggesting that $\mathrm{Ni}(\mathrm{II})$ interacts principally with weak sites (which are well described by the broadening toward low energy distribution assumed by Toth equation). Conversely, Co(II) adsorption is better interpreted by Freundlich model, indicating preferential interaction of the cation with stronger sites (which are in this case described by the exponential decreasing trend of the energy 
distribution of adsorption sites). As previously discussed, literature confirms that synthetic HAP presents a not negligible amount of carbonate groups on the surface (Campisi et al. 2018; Silvester et al. 2014). In fact, HAP surface exhibits at least three different sites: hydroxyl, carbonate and phosphate groups. These sites interact with different strength with metal species. Stability constant (Martell 2013) of the corresponding metal-site complex can be considered indexes of interaction strength. From this point of view, both $\mathrm{Ni}(\mathrm{II})$ and $\mathrm{Co}(\mathrm{II})$ species exhibit strong $\left(\mathrm{K}_{\mathrm{c}} \mathrm{ca} .10^{-15}\right)$ and very weak $\left(\mathrm{K}_{\mathrm{c}} \mathrm{ca} \cdot 10^{-2}\right)$ interaction with $\mathrm{OH}-$ and $\mathrm{PO}_{4}{ }^{3-}$, respectively. Relevant difference can be noted when carbonate groups are involved: $\mathrm{Co}(\mathrm{II})$ present a $\mathrm{K}_{\mathrm{c}}$ around $10^{-10}$ while $\mathrm{Ni}(\mathrm{II})$ one attested around $10^{-7}$

\subsubsection{Bimetallic pool adsorption isotherms}

Considering that both $\mathrm{Ni}(\mathrm{II})$ and $\mathrm{Co}(\mathrm{II})$ are likely adsorbed onto HAP surface with the same mechanism (supposed to be surface complexation), it is fundamental to investigate the competitive effects in the adsorption onto HAP when $\mathrm{Ni}(\mathrm{II})$ and $\mathrm{Co}(\mathrm{II})$ are co-present in solution. An adsorption isotherm was then collected starting from $\mathrm{Ni}(\mathrm{II})+\mathrm{Co}(\mathrm{II})$ equimolar solutions; for each experimental point, the total and single metal equilibrium concentration and adsorption uptake were measured. Once collecting the isotherm of $\mathrm{Ni}(\mathrm{II})+\mathrm{Co}(\mathrm{II})$ adsorption, the $\mathrm{Ni}$ (II) and $\mathrm{Co}(\mathrm{II})$ separated isotherms have been drawn and fitted with the relevant most suitable equation model already identified from the single metal adsorption isotherms (Freundlich model for Co(II) and Toth model for Ni(II), Fig. 5). However, fitting the separated $\mathrm{Ni}(\mathrm{II})$ and $\mathrm{Co}$ (II) experimental data with the Langmuir isotherm, good correlation coefficients could be obtained $\left(\mathrm{R}^{2}=0.935\right.$ for $\mathrm{Ni}(\mathrm{II})$ and 0.992 for $\mathrm{Co}(\mathrm{II})$, Table 4$)$. As discussed in paragraph 3.3.1, HAP surface does not fulfill Langmuir model assumptions, but it is useful in determining maximum adsorption capacity of target ions on given sorbents. The value of

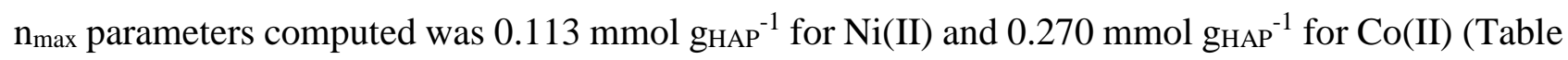
4). Since the sum of $n_{\max }\left(0.383 \mathrm{mmol}_{(\mathrm{Ni}+\mathrm{Co})} \mathrm{g}_{\mathrm{HAP}}{ }^{-1}\right)$ is almost equal to the $\mathrm{n}_{\max }$ obtained from the $\mathrm{Co}(\mathrm{II})$ adsorption in the $\mathrm{Ni}(\mathrm{II})+\mathrm{Co}(\mathrm{I})$ isotherm, it can be guessed that when $\mathrm{Ni}$ (II) and $\mathrm{Co}(\mathrm{II})$ are co- 
present, they compete for HAP adsorption on the same sites with a marked winning effect of $\mathrm{Co}$ (II). Considering the higher affinity of the carbonate groups for Co(II), competition on these adsorption sites is in favor of this species, contributing to the higher selectivity of the adsorption process to Co(II) than $\mathrm{Ni}(\mathrm{II})$. Experimental data fitting of the linearized forms of all the model adsorption isotherms applied on the $\mathrm{Ni}(\mathrm{II})+\mathrm{Co}(\mathrm{II})$ pool are reported in Fig. S4.

\section{Conclusions}

Synthetic HAP proved satisfactory ability in trapping $\mathrm{Ni}(\mathrm{II})$ and $\mathrm{Co}(\mathrm{II})$ ions onto its surface. Adsorption sites (hydroxyl, carbonate and phosphate groups) interact with different strength with the two metal species, determining different maximum sorption capacities $\left(\mathrm{n}_{\max }\right)$ when $\mathrm{Ni}$ (II) and $\mathrm{Co}$ (II) are individually present in solution. In binary solutions, $\mathrm{Ni}(\mathrm{II})$ and $\mathrm{Co}(\mathrm{II})$ seem to compete for the adsorption on the same sites of the HAP surface. The higher affinity of HAP toward Co(II) has been observed and proven by computation starting from the collected adsorption isotherms.

Because of the absence of growth of new crystalline phases or shifts on XRPD patterns of Ni- and Co-loaded HAP, the most likely adsorption mechanism may be the surface complexation.

Even if Langmuir isotherm resulted to be the good model to describe the adsorption processes onto HAP for both metal species, Temkin isotherm even better fitted the experimental data, suggesting not negligible adsorbate-adsorbate lateral interaction. Flory-Huggins isotherm allowed to evaluate the spontaneity of the adsorption processes, indicating $\mathrm{Co}(\mathrm{II})$ as more affine to HAP. The higher affinity of HAP towards $\mathrm{Co}(\mathrm{II})$ rather than $\mathrm{Ni}$ (II) could be ascribed to the stronger interaction of cobalt ions with the functional groups present at HAP surface. In particular Co(II) is able to establish very strong interactions with carbonate and hydroxide groups, while just weak interactions with these groups are involved in the $\mathrm{Ni}$ (II) uptake. The different affinity emerged mainly when an equimolar Co-Ni binary solution was put in contact with HAP. In this case, Ni(II) suffers from the preferential interaction of HAP with Co, resulting un favored in the competition, as reflected by the observed 2.5:1 $\mathrm{n}_{\max , \operatorname{Co}(\mathrm{II})}$ : $\mathrm{n}_{\max , \mathrm{Ni}(\mathrm{II})}$ ratio. However, if the relative differences between $\mathrm{Co}(\mathrm{II})$ and $\mathrm{Ni}$ (II) could be explained in 
terms of interaction strength with the HAP surface groups, further studies are still necessary to understand the low adsorption site tendency of HAP towards Ni(II) also in the single-metal tests. This study also shows the importance of the synthesis of different HAP solids with low or high presence of surface carbonate groups to modulate the adsorption properties towards given adsorbates. Carbonate groups, substituting phosphate and/or hydroxyl groups at the HAP surface, play an important role in the adsorption process; they have strong adsorption ability and can modulate the adsorption strength of the surface.

\section{References}

Anoop Krishnan, K., Sreejalekshmi, K.G., Baiju, R.S.: Nickel(II) adsorption onto biomass based activated carbon obtained from sugarcane bagasse pith. Bioresour. Technol. 102, 10239-10247 (2011). doi:10.1016/j.biortech.2011.08.069

Ayawei, N., Ebelegi, A.N., Wankasi, D.: Modelling and Interpretation of Adsorption Isotherms. J. Chem. 2017, (2017). doi:10.1155/2017/3039817

Babel, S., Kurniawan, T.A.: Low-cost adsorbents for heavy metals uptake from contaminated water: A review. J. Hazard. Mater. 97, 219-243 (2003). doi:10.1016/S03043894(02)00263-7

Bailey, S.E., Olin, T.J., Mark Bricka, R., Dean Adrian, D.: and 2 USAE Waterways Experiment Station, 3909 Halls Ferry Rd. 33, (1999)

Benzaoui, T., Selatnia, A., Djabali, D.: Adsorption of copper (II) ions from aqueous solution using bottom ash of expired drugs incineration. Adsorpt. Sci. Technol. 36, 114-129 (2018). doi:10.1177/0263617416685099

Campisi, S., Castellano, C., Gervasini, A.: Tailoring the structural and morphological properties of hydroxyapatite materials to enhance the capture efficiency towards copper(II) 
and lead(II) ions. New J. Chem. 42, 4520-4530 (2018). doi:10.1039/C8NJ00468D

Campisi, S., Galloni, M.G., Bossola, F., Gervasini, A.: Comparative performance of copper and iron functionalized hydroxyapatite catalysts in NH3 -SCR. Catal. Commun. 123, 79-85 (2019). doi:10.1016/j.catcom.2019.02.008

Chaney et. al.: Method for phytomining of nickel, cobalt and other metals from soil. United States Pat. 711,784 (1998). doi:10.4191/kcers.2011.48.6.641

Chen, C.H., Liu, J., Stoll, M.E., Henriksen, G., Vissers, D.R., Amine, K.: Aluminum-doped lithium nickel cobalt oxide electrodes for high-power lithium-ion batteries. J. Power Sources. 128, 278-285 (2004). doi:10.1016/j.jpowsour.2003.10.009

Chen, S.B., Ma, Y.B., Chen, L., Xian, K.: Adsorption of aqueous Cd2+, $\mathrm{Pb} 2+, \mathrm{Cu} 2+$ ions by nano-hydroxyapatite: Single-and multi-metal competitive adsorption study. Geochem. J. 44, 233-239 (2010). doi:10.2343/geochemj.1.0065

Chmielewskà-Horvthovà, E., Lesny, J.: Adsorption of cobalt on some natural zeolites occurring in CSFR. J. Radioanal. Nucl. Chem., Lett. 166, 13 (1992). doi:https://doi.org/10.1007/BF02167997

Corami, A., Mignardi, S., Ferrini, V.: Cadmium removal from single- and multi-metal $(\mathrm{Cd}$ $+\mathrm{Pb}+\mathrm{Zn}+\mathrm{Cu}$ ) solutions by sorption on hydroxyapatite. J. Colloid Interface Sci. 317, 402408 (2008). doi:10.1016/j.jcis.2007.09.075

Corbala-Robles, L., Volcke, E.I.P., Samijn, A., Ronsse, F., Pieters, J.G.: Effect of foam on temperature prediction and heat recovery potential from biological wastewater treatment. Water Res. 95, 340-347 (2016). doi:10.1016/j.watres.2016.03.031

Dean, J.G., Bosqui, F.L., Lanouette, K.H.: Removing heavy metals from waste water. Environ. Sci. Technol. 6, 518-522 (1972). doi:10.1021/es60065a006

Fetcenko, M.A., Ovshinsky, S.R., Reichman, B., Young, K., Fierro, C., Koch, J., Zallen, 
A., Mays, W., Ouchi, T.: Recent advances in NiMH battery technology. J. Power Sources. 165, 544-551 (2007). doi:10.1016/j.jpowsour.2006.10.036

Fihri, A., Len, C., Varma, R.S., Solhy, A.: Hydroxyapatite: A review of syntheses, structure and applications in heterogeneous catalysis. Coord. Chem. Rev. 347, 48-76 (2017). doi:10.1016/j.ccr.2017.06.009

Flores-Cano, J.V., Leyva-Ramos, R., Carrasco-Marin, F., Aragòn-Pina, A., SalazarRabago, J.J., Leyva-Ramos, S.: Adsorption mechanism of Chromium(III) from water solution on bone char: effect of operating conditions. Adsorption. 22, 297-308 (2016). doi:10.1007/s10450-016-9771-3

Gupta, N., Kushwaha, A.K., Chattopadhyaya, M.C.: Adsorptive removal of $\mathrm{Pb} 2+, \mathrm{Co} 2+$ and $\mathrm{Ni2}+$ by hydroxyapatite/chitosan composite from aqueous solution. J. Taiwan Inst. Chem. Eng. 43, 125-131 (2012). doi:10.1016/j.jtice.2011.07.009

Howe, P.D., Kingdom, U.: Cobalt and Inorganic Cobalt. IPCS Concise Int. Chem. Assess. Doc. 69, 1-93 (2006)

Janusz, W., Skwarek, E.: Effect of Co(II) ions adsorption in the hydroxyapatite/aqueous $\mathrm{NaClO} 4$ solution system on particles electrokinetics. Physicochem. Probl. Miner. Process. 54, 31-39 (2018). doi:10.5277/ppmp1810

Lamonier, C., Lamonier, J.F., Aellach, B., Ezzamarty, A., Leglise, J.: Specific tuning of $\mathrm{acid} / \mathrm{base}$ sites in apatite materials to enhance their methanol thiolation catalytic performances. Catal. Today. 164, 124-130 (2011). doi:10.1016/j.cattod.2010.10.035 Liss, P.S., Slater, P.G.: (C 1974 Nature Publishing Group. News Views. (1974) Ma, Q.Y., Traina, S.J., Logan, T.J., Ryan, J.A.: Effects of Aqueous Al, Cd, Cu, Fe(II), Ni, and $\mathrm{Zn}$ on Pb Immobilization by Hydroxyapatite. Environ. Sci. Technol. 28, 1219-1228 (1994). doi:10.1021/es00056a007 
Martell, A.: Critical Stability Constants: Inorganic Complexes. Springer US (2013)

McAnally, S., Benefield, L., Reed, R.B.: Nickel Removal from a Synthetic Nickel-Plating Wastewater Using Sulfide and Carbonate for Precipitation and Coprecipitation. Sep. Sci. Technol. 19, 191-217 (1984). doi:10.1080/01496398408060655

Medellin-Castillo, N.A., Padilla-Ortega, E., Regules-Martínez, M.C., Leyva-Ramos, R., Ocampo-Pérez, R., Carranza-Alvarez, C.: Single and competitive adsorption of Cd(II) and $\mathrm{Pb}(\mathrm{II})$ ions from aqueous solutions onto industrial chili seeds (Capsicum annuum) waste. Sustain. Environ. Res. 27, 61-69 (2017). doi:10.1016/j.serj.2017.01.004

Meejoo, S., Maneeprakorn, W., Winotai, P.: Phase and thermal stability of nanocrystalline hydroxyapatite prepared via microwave heating. Thermochim. Acta. 447, 115-120 (2006). doi:10.1016/j.tca.2006.04.013

Meyer, J.L. Eanes, E.D.: Phosphate Transformation. Calcif. Tiss. Res. 25, 59-68 (1978) Mobasherpour, I., Salahi, E., Pazouki, M.: Removal of nickel (II) from aqueous solutions by using nano-crystalline calcium hydroxyapatite. J. Saudi Chem. Soc. 15, 105-112 (2011). doi:10.1016/j.jscs.2010.06.003

Mobasherpour, I., Salahi, E., Pazouki, M.: Comparative of the removal of $\mathrm{Pb} 2+, \mathrm{Cd} 2+$ and Ni2+by nano crystallite hydroxyapatite from aqueous solutions: Adsorption isotherm study. Arab. J. Chem. 5, 439-446 (2012). doi:10.1016/j.arabjc.2010.12.022

Mohammad, A.M., Salah Eldin, T.A., Hassan, M.A., El-Anadouli, B.E.: Efficient treatment of lead-containing wastewater by hydroxyapatite/chitosan nanostructures. Arab. J. Chem. 10, 683-690 (2017). doi:10.1016/j.arabjc.2014.12.016

Mousa, S.M., Ammar, N.S., Ibrahim, H.A.: Removal of lead ions using hydroxyapatite nano-material prepared from phosphogypsum waste. J. Saudi Chem. Soc. 20, 357-365 (2016). doi:10.1016/j.jscs.2014.12.006 
Nackerdien, Z., Kasprzak, K.S., Rao, G., Halliwell, B., Dizdaroglu, M.: Nickel( II ) - and Cobalt( II ) -dependent Damage by Hydrogen Peroxide to the DNA Bases in Isolated Human Chromatin Nickel ( H ) - and Cobalt ( II ) -dependent Damage by Hydrogen Peroxide to the DNA Bases in Isolated Human Chromatin1. Cancer Res. 51, 5837-5842 (1991)

Pham Minh, D., Tran, N.D., Nzihou, A., Sharrock, P.: Hydroxyapatite gel for the improved removal of $\mathrm{Pb} 2+$ ions from aqueous solution. Chem. Eng. J. 232, 128-138 (2013). doi:10.1016/j.cej.2013.07.086

Rabah, M.A., Farghaly, F.E., Abd-El Motaleb, M.A.: Recovery of nickel, cobalt and some salts from spent Ni-MH batteries. Waste Manag. 28, 1159-1167 (2008).

doi:10.1016/j.wasman.2007.06.007

Recillas, S., Rodríguez-Lugo, V., Montero, M.L., Viquez-Cano, S., Hernandez, L.,

Castaño, V.M.: Studies on the precipitation behavior of calcium phosphate solutions. J.

Ceram. Process. Res. 13, 5-10 (2012)

Reichert, J., Binner, J.G.P.: An evaluation of hydroxyapatite-based filters for removal of heavy metal ions from aqueous solutions. J. Mater. Sci. 31, 1231-1241 (1996). doi:10.1007/BF00353102

Rivera-Munoz, E.M.: Hydroxyapatite-Based Materials: Synthesis and Characterization. In: Biomedical Engineering - Frontiers and Challenges. pp. 75-98. InTech (2011) Rosskopfová, O., Galamboš, M., Pivarčiová, L., Čaplovičová, M., Rajec, P.: Adsorption of nickel on synthetic hydroxyapatite from aqueous solutions. J. Radioanal. Nucl. Chem. 295, 459-465 (2013). doi:10.1007/s10967-012-1799-6

Rötting, T.S., Cama, J., Ayora, C., Cortina, J.L., De Pablo, J.: Use of caustic magnesia to remove cadmium, nickel, and cobalt from water in passive treatment systems: Column 
experiments. Environ. Sci. Technol. 40, 6438-6443 (2006). doi:10.1021/es061092g Schiavoni, M., Campisi, S., Carniti, P., Gervasini, A., Delplanche, T.: Focus on the catalytic performances of $\mathrm{Cu}$-functionalized hydroxyapatites in NH3-SCR reaction. Appl. Catal. A Gen. 563, 43-53 (2018). doi:10.1016/j.apcata.2018.06.020

Silvester, L., Lamonier, J.F., Vannier, R.N., Lamonier, C., Capron, M., Mamede, A.S., Pourpoint, F., Gervasini, A., Dumeignil, F.: Structural, textural and acid-base properties of carbonate-containing hydroxyapatites. J. Mater. Chem. A. 2, 11073-11090 (2014). doi:10.1039/c4ta01628a

Singh, J.S., Abhilash, P.C., Singh, H.B., Singh, R.P., Singh, D.P.: Genetically engineered bacteria: An emerging tool for environmental remediation and future research perspectives. Gene. 480, 1-9 (2011)(a). doi:10.1016/j.gene.2011.03.001

Singh, R., Gautam, N., Mishra, A., Gupta, R.: Heavy metals and living systems: An overview. Indian J. Pharmacol. 43, 246 (2011)(b). doi:10.4103/0253-7613.81505

Skwarek, E., Janusz, W.: Adsorption of Cd(II) ions at the hydroxyapatite/electrolyte solution interface. Sep. Sci. Technol. 51, 11-21 (2016).

doi:10.1080/01496395.2015.1085878

Smičiklas, I., Dimović, S., Plećaš, I., Mitrić, M.: Removal of Co2+from aqueous solutions by hydroxyapatite. Water Res. 40, 2267-2274 (2006). doi:10.1016/j.watres.2006.04.031 Smičiklas, I., Onjia, A., Raičević, S., Janaćković, D.: Factors influencing the removal of divalent cations by hydroxyapatite. J. Hazard. Mater. 168, 560-562 (2009). doi:10.1016/j.jhazmat.2009.01.137 Smičiklas, I.D., Milonjić, S.K., Pfendt, P., Raičević, S.: The point of zero charge and sorption of cadmium (II) and strontium (II) ions on synthetic hydroxyapatite. Sep. Purif. Technol. 18, 185-194 (2000). doi:10.1016/S1383-5866(99)00066-0 
Sprynskyy, M., Buszewski, B., Terzyk, A.P., Namieśnik, J.: Study of the selection mechanism of heavy metal $(\mathrm{Pb} 2+, \mathrm{Cu} 2+, \mathrm{Ni} 2+$, and $\mathrm{Cd} 2+)$ adsorption on clinoptilolite. $\mathrm{J}$. Colloid Interface Sci. 304, 21-28 (2006). doi:10.1016/j.jcis.2006.07.068 WHO: Drinking Water Parameter Cooperation Project: Support to the revision of Annex I Council Directive 98 / 83 / EC on the Quality of Water Intended for Human Consumption ( Drinking Water Directive ) Recommendations. (2017)

Zhu, R., Yu, R., Yao, J., Mao, D., Xing, C., Wang, D.: Removal of Cd2+from aqueous solutions by hydroxyapatite. Catal. Today. 139, 94-99 (2008).

doi:10.1016/j.cattod.2008.08.011 


\section{FIGURES}
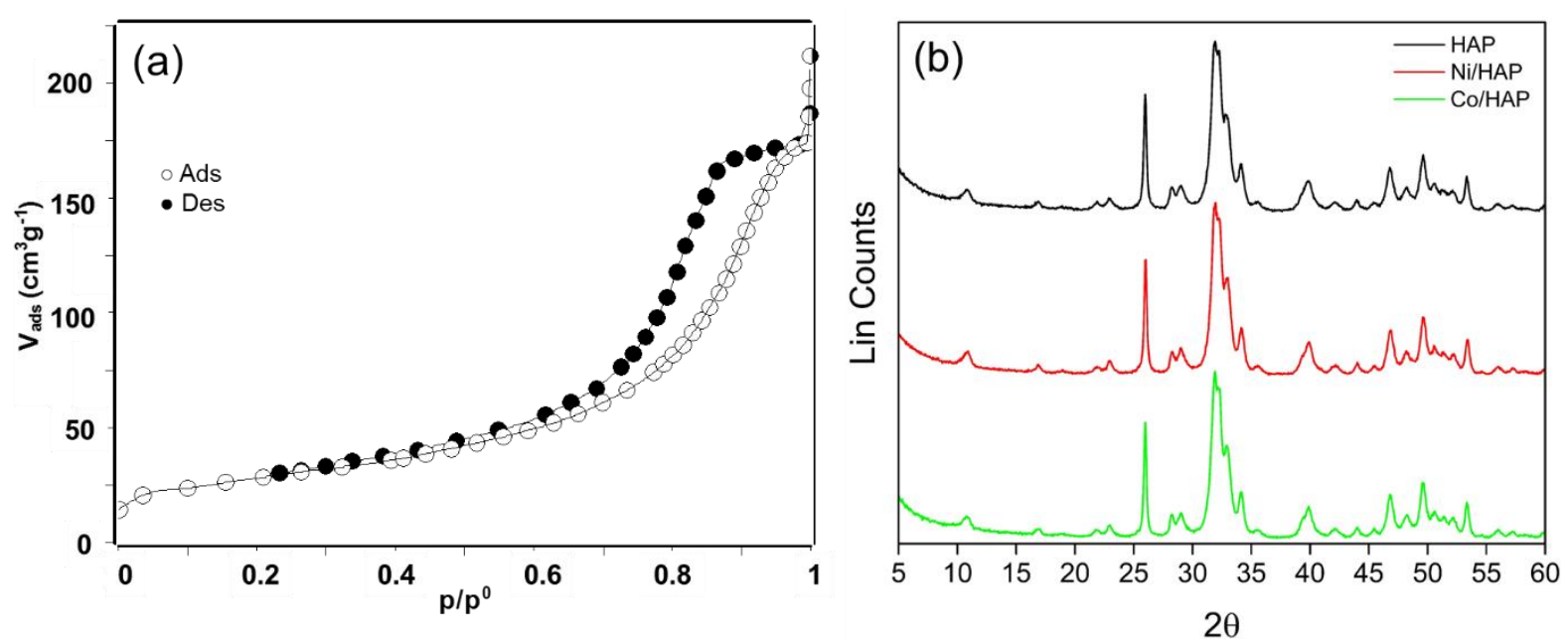

Fig. 1. $\mathrm{N}_{2}$ adsorption-desorption isotherms of synthetic HAP (a) and XRPD patterns (b) of as prepared HAP $(-)$, Ni-loaded HAP $(-)$ and Co-loaded HAP $(-)$ as obtained after the static batch adsorption tests of $\mathrm{Co}(\mathrm{II})$ and $\mathrm{Ni}(\mathrm{II})$ on HAP.

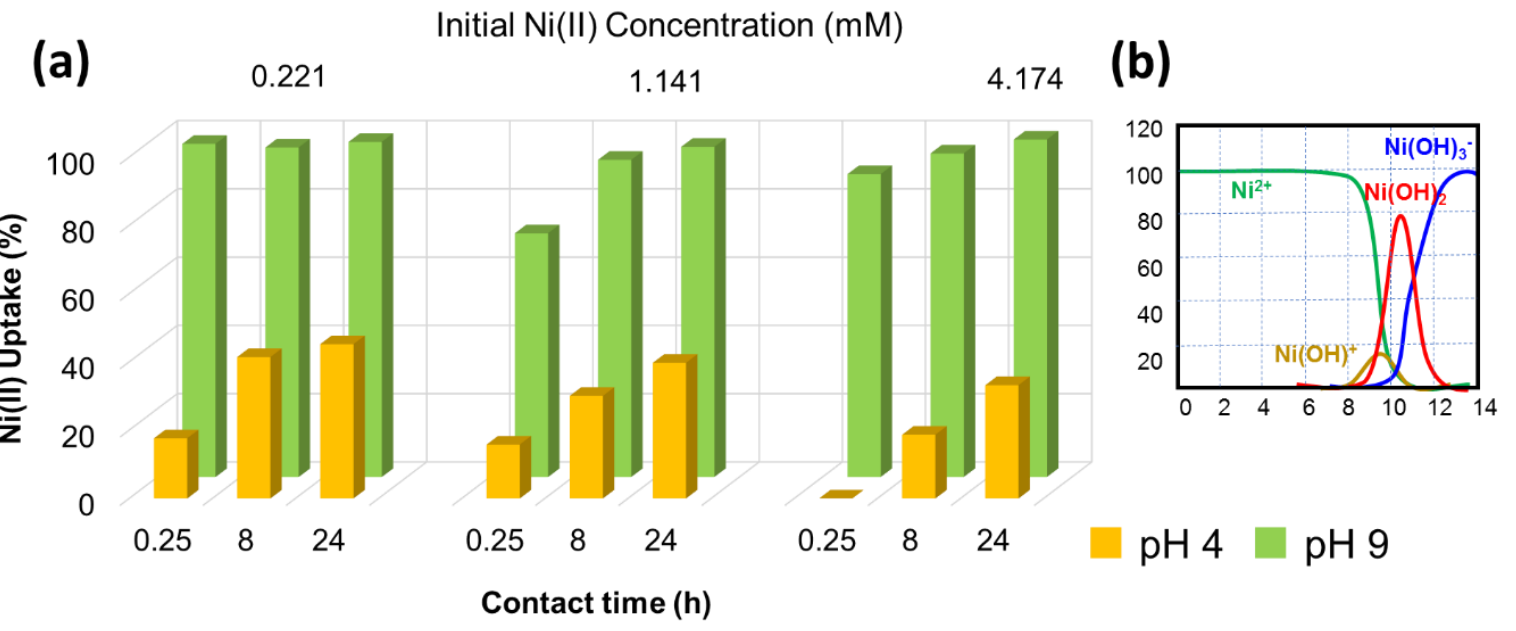

Fig. 2. $\mathrm{Ni}(\mathrm{II})$ uptake (\%) on synthetic HAP (a) from static batch adsorption tests, carried out at $30^{\circ} \mathrm{C}$, solid to solution ratio ca. 1:100 (g/mL); $\mathrm{Ni}(\mathrm{II})$ speciation in aqueous solution (b). 


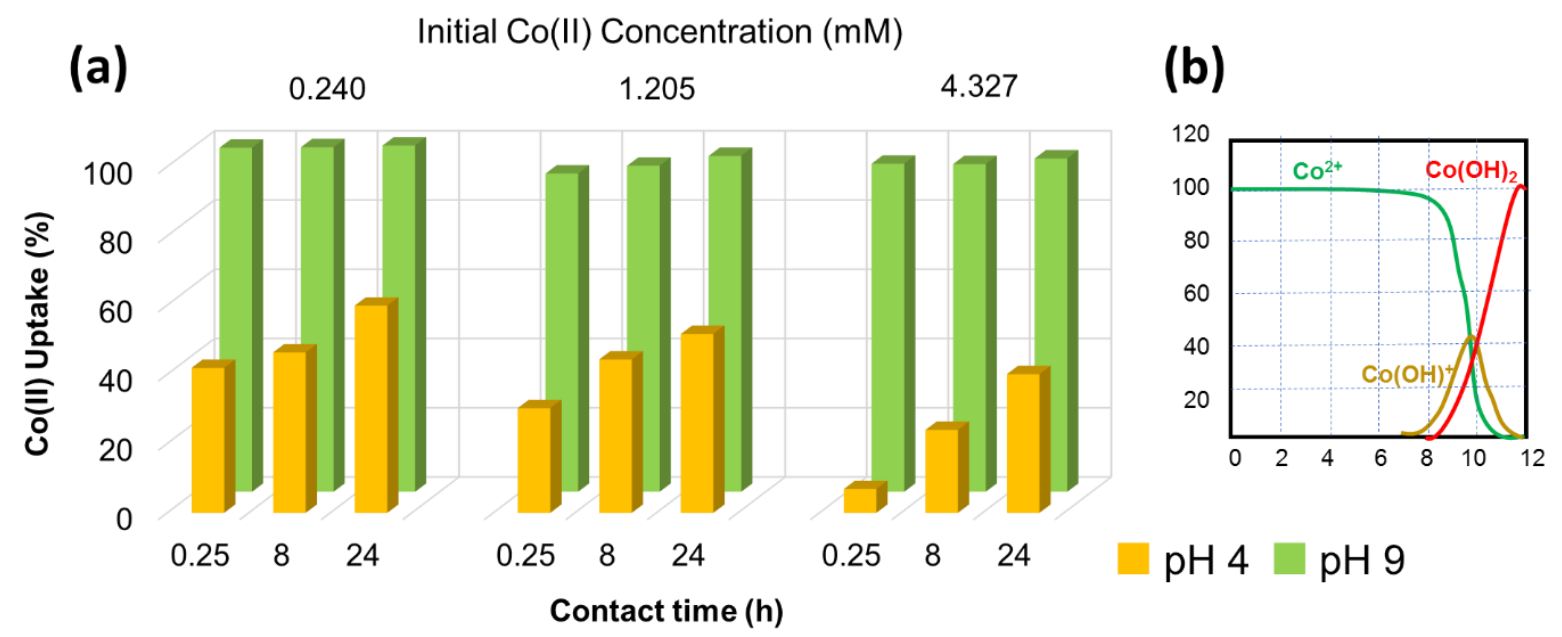

Fig. 3. Co(II) uptake (\%) on synthetic HAP (a) from static batch adsorption tests, carried out at $30^{\circ} \mathrm{C}$, solid to solution ratio ca. 1:100 (g/mL); Co(II) speciation in aqueous solution (b).
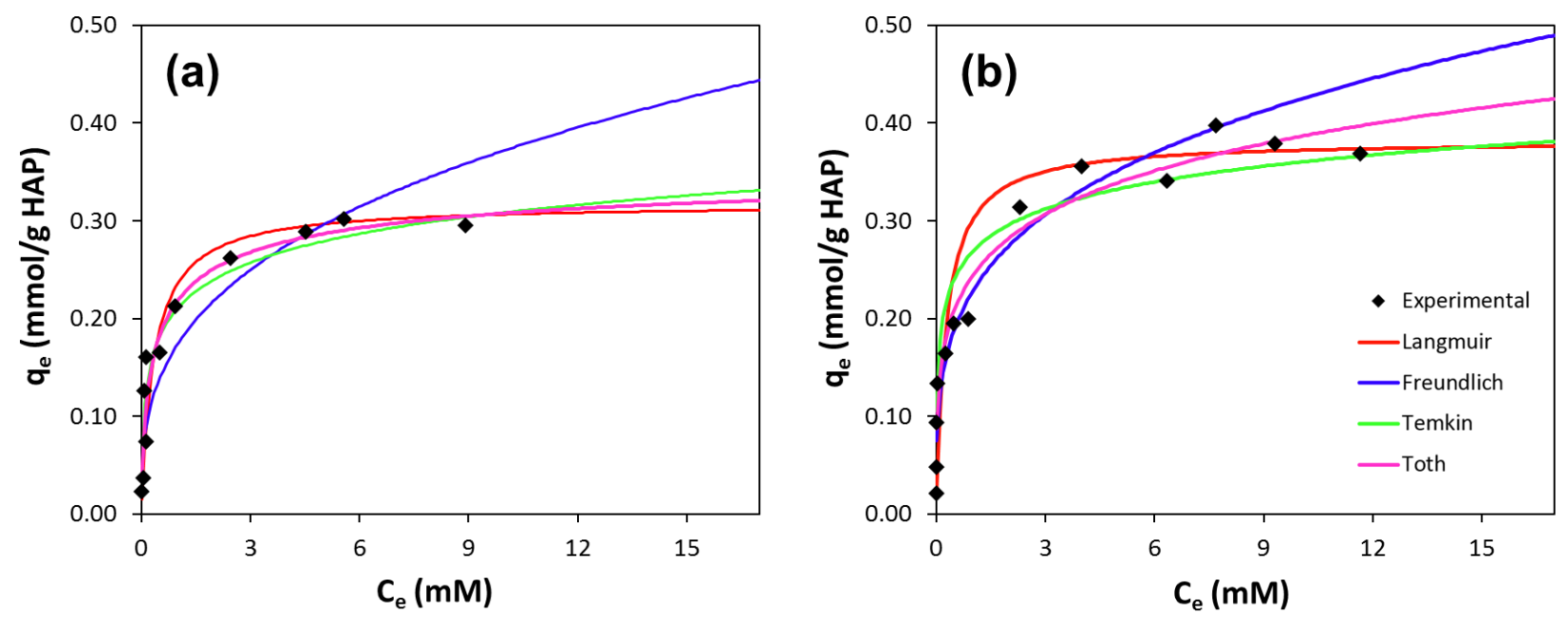

Fig. 4. Experimental and fitted adsorption isotherms of nickel (a) and cobalt (b) on HAP. Experiments have been carried out at $30^{\circ} \mathrm{C}, \mathrm{pH} 4$, solid to solution ratio ca. $1: 100(\mathrm{~g} / \mathrm{mL})$; for each point, equilibrium was attained after $2 \mathrm{~h}$ contact time under vigorous stirring. 


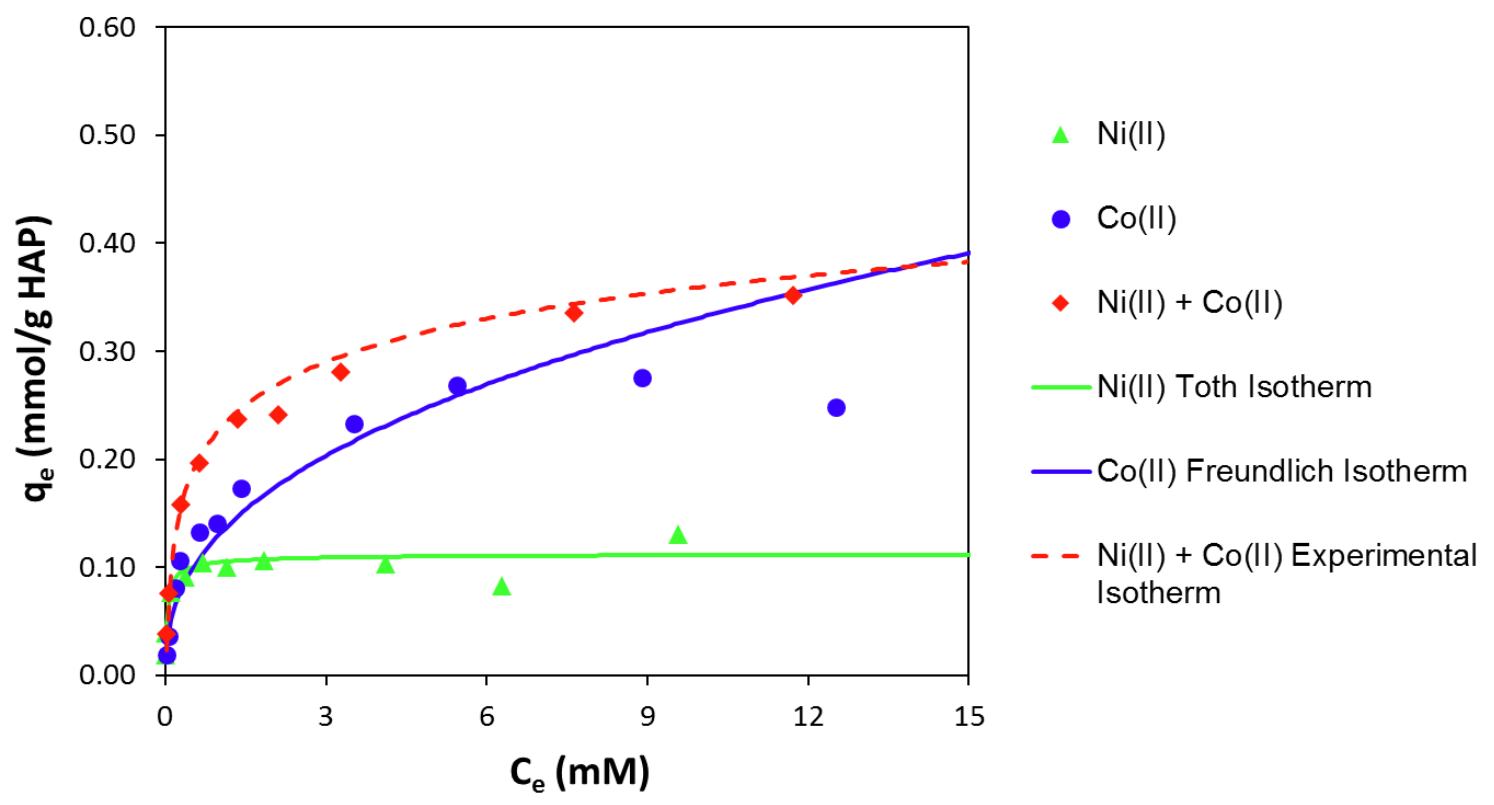

Fig. 5. Experimental adsorption isotherms of nickel and cobalt co-present in solution on HAP at $30^{\circ} \mathrm{C}, \mathrm{pH} 4$, solid to solution ratio ca. $1: 100(\mathrm{~g} / \mathrm{mL})$, for each point, equilibrium was attained after $2 \mathrm{~h}$ contact time under vigorous stirring. The $\mathrm{Ni}(\mathrm{II})+\mathrm{Co}(\mathrm{II})$ adsorption Isotherm has been decomposed into two single isotherms describing the adsorption of nickel and of cobalt, respectively. The computed isotherms of $\mathrm{Ni}$ and of $\mathrm{Co}$ have been modelled with the relevant best fitting model equation (see Fig. 4). 


\section{TABLES}

Table 1. Compositional and morphological properties of synthetic HAP.

\begin{tabular}{lllll}
\hline & $\begin{array}{l}\text { Ca/P ratio } \\
(\text { molar })\end{array}$ & $\begin{array}{l}\text { Surface area }^{\mathrm{b}} \\
\left(\mathrm{m}^{2} \mathrm{~g}^{-1}\right)\end{array}$ & $\begin{array}{l}\text { Mean pore radius } \\
(\mathrm{nm})\end{array}$ & $\begin{array}{l}\text { Pore volume }^{\mathrm{c}} \\
\left(\mathrm{cm}^{3} \mathrm{~g}^{-1}\right)\end{array}$ \\
\hline Synthetic HAP & 1.689 & 100.5 & 5.21 & 0.272 \\
\hline
\end{tabular}

a Measured by ICP-AES on mineralized sample.

${ }^{b}$ Evaluated according to 3-parameter BET model.

c Evaluated according to B.J.H. model.

Table 2. Amounts of nickel and cobalt uptake on HAP measured from static batch single metal adsorption tests at $30^{\circ} \mathrm{C}$, solid to solution ratio ca. $1: 100$ (in $\mathrm{g} / \mathrm{mL}$ ), at different $\mathrm{pH}$, initial metal concentration and contact time.

\begin{tabular}{|c|c|c|c|c|c|c|}
\hline \multirow{4}{*}{$\begin{array}{l}\text { Contact time } \\
\text { (h) }\end{array}$} & \multicolumn{6}{|c|}{$\mathrm{Ni}(\mathrm{II})$ adsorbed (mmol/g $\left.\mathrm{g}_{\text {HAP }}\right)$} \\
\hline & \multicolumn{3}{|c|}{ pH 4} & \multicolumn{3}{|c|}{ pH 9} \\
\hline & \multicolumn{6}{|c|}{ Initial Ni(II) Concentration } \\
\hline & $0.221 \mathrm{mM}$ & $1.141 \mathrm{mM}$ & $4.174 \mathrm{mM}$ & $0.221 \mathrm{mM}$ & $1.141 \mathrm{mM}$ & $4.174 \mathrm{mM}$ \\
\hline 0.25 & 0.00336 & 0.0185 & 0 & 0.0234 & 0.0788 & 0.337 \\
\hline 8 & 0.00822 & 0.0350 & 0.0907 & 0.0226 & 0.105 & 0.362 \\
\hline \multirow[t]{3}{*}{24} & 0.00889 & 0.0475 & 0.132 & 0.0231 & 0.104 & 0.368 \\
\hline & \multicolumn{6}{|c|}{ Co(II) adsorbed (mmol/g $\left.g_{\text {HAP }}\right)$} \\
\hline & \multicolumn{3}{|c|}{$\mathrm{pH} 4$} & \multicolumn{3}{|c|}{$\mathrm{pH} 9$} \\
\hline \multirow{2}{*}{$\begin{array}{l}\text { Contact time } \\
\text { (h) }\end{array}$} & \multicolumn{6}{|c|}{ Initial Co(II) Concentration } \\
\hline & $0.240 \mathrm{mM}$ & $1.205 \mathrm{mM}$ & $4.327 \mathrm{mM}$ & $0.240 \mathrm{mM}$ & $1.205 \mathrm{mM}$ & $4.327 \mathrm{mM}$ \\
\hline 0.25 & 0.0097 & 0.0357 & 0.0289 & 0.0252 & 0.104 & 0.418 \\
\hline 8 & 0.0100 & 0.0556 & 0.0980 & 0.0237 & 0.114 & 0.453 \\
\hline 24 & 0.0145 & 0.0642 & 0.165 & 0.0234 & 0.112 & 0.442 \\
\hline
\end{tabular}


Table 3. Calculated parameters obtained from experimental data of single $\mathrm{Ni}$ (II) and $\mathrm{Co}$ (II) adsorption isotherms

\begin{tabular}{|c|c|c|c|c|c|c|c|}
\hline \multirow{2}{*}{ Isotherm Model } & \multirow{2}{*}{$\begin{array}{c}\text { Parameter } \\
\mathrm{n}_{\max }\left(m m o l g_{H A P^{-1}}\right)\end{array}$} & \multicolumn{3}{|c|}{$\mathrm{Ni}(\mathrm{II})$} & \multicolumn{3}{|c|}{$\mathrm{Co}(\mathrm{II})$} \\
\hline & & 0.317 & \pm & 0.004 & 0.382 & \pm & 0.009 \\
\hline \multirow{3}{*}{ Langmuir } & $\mathrm{b}_{\mathrm{ads}}\left(\mathrm{Lmmol}^{-1}\right)$ & 2.88 & \pm & 0.59 & 3.70 & \pm & 1.66 \\
\hline & $\mathrm{R}^{2}$ & 0.998 & & & 0.994 & & \\
\hline & $\mathrm{n}_{\mathrm{F}}$ & 3.02 & \pm & 0.42 & 3.70 & \pm & 0.25 \\
\hline \multirow[t]{3}{*}{ Freundlich } & $\mathrm{K}_{\mathrm{F}}\left(m m o l g_{\text {HAP }^{-1}}\right)$ & 0.174 & \pm & 0.0108 & 0.228 & \pm & 0.00924 \\
\hline & $\mathrm{R}^{2}$ & 0.838 & & & 0.951 & & \\
\hline & $\mathrm{B}\left(\mathrm{J} \mathrm{mmol}^{-1}\right)$ & 0.0426 & \pm & 0.004 & 0.0398 & \pm & 0.003 \\
\hline \multirow[t]{2}{*}{ Temkin } & $\mathrm{A}_{\mathrm{T}}\left(\mathrm{L} \mathrm{mmol}^{-1}\right)$ & 140 & \pm & 13.9 & 850 & \pm & 75.5 \\
\hline & $\mathrm{R}^{2}$ & 0.925 & & & 0.934 & & \\
\hline \multirow{4}{*}{ Toth } & $\mathrm{n}_{\max }\left(m m o l g_{H A P^{-1}}\right)$ & 0.317 & \pm & 0.008 & 0.382 & \pm & 0.019 \\
\hline & $\mathrm{b}_{\mathrm{ads}}\left(\mathrm{L} \mathrm{mmol}^{-1}\right)$ & 7.70 & \pm & 1.24 & 51.8 & \pm & 10.3 \\
\hline & $\mathrm{n}$ & 0.805 & \pm & 0.0848 & 0.559 & \pm & 0.0845 \\
\hline & $\mathrm{R}^{2}$ & 0.900 & & & 0.814 & & \\
\hline \multirow{4}{*}{ Flory-Huggins } & $\mathrm{n}$ & 0.406 & \pm & 0.031 & 0.318 & \pm & 0.040 \\
\hline & $\mathrm{K}_{\mathrm{FH}}\left(\mathrm{L} \mathrm{mmol}^{-1}\right)$ & 0.327 & \pm & 0.021 & 0.259 & \pm & 0.0215 \\
\hline & $\Delta \mathrm{G}^{0}\left(\mathrm{~J} \mathrm{mmol}^{-1}\right)$ & -2.82 & \pm & 0.178 & -3.40 & \pm & 0.205 \\
\hline & $\mathrm{R}^{2}$ & 0.945 & & & 0.863 & & \\
\hline
\end{tabular}


Table 4. Calculated parameters obtained from experimental data of the $\mathrm{Ni}(\mathrm{II})+\mathrm{Co}(\mathrm{II})$ adsorption isotherm

\begin{tabular}{|c|c|c|c|c|c|}
\hline & Isotherm Model & Parameter & & & \\
\hline \multirow{7}{*}{$\mathrm{Ni}(\mathrm{II})$} & \multirow{3}{*}{ Langmuir } & $\mathrm{n}_{\max }\left(m m o l g_{\text {HAP }}{ }^{-1}\right)$ & 0.113 & \pm & 0.011 \\
\hline & & $\mathrm{b}_{\text {ads }}\left(\mathrm{L} \mathrm{mmol}^{-1}\right)$ & 5.15 & \pm & 9.68 \\
\hline & & $\mathrm{R}^{2}$ & 0.935 & & \\
\hline & \multirow{4}{*}{ Toth } & $\mathrm{n}_{\max }\left(m m o l g_{\text {HAP }}{ }^{-1}\right)$ & 0.113 & \pm & 0.003 \\
\hline & & $\mathrm{b}_{\mathrm{ads}}\left(\mathrm{L} \mathrm{mmol}^{-1}\right)$ & 76.9 & \pm & 19 \\
\hline & & $\mathrm{n}$ & 0.679 & \pm & 0.16 \\
\hline & & $\mathrm{R}^{2}$ & 0.853 & & \\
\hline \multirow{6}{*}{$\mathrm{Co}(\mathrm{II})$} & \multirow{3}{*}{ Langmuir } & $\mathrm{n}_{\max }\left(m m o l g_{\text {HAP }}{ }^{-1}\right)$ & 0.270 & \pm & 0.008 \\
\hline & & $\mathrm{b}_{\text {ads }}\left(L_{m m o l}{ }^{-1}\right)$ & 2.04 & \pm & 0.62 \\
\hline & & $\mathrm{R}^{2}$ & 0.992 & & \\
\hline & \multirow{3}{*}{ Freundlich } & $\mathrm{n}_{\mathrm{F}}$ & 2.46 & \pm & 0.25 \\
\hline & & $\mathrm{K}_{\mathrm{F}}\left(m m o l g_{H^{\prime} P^{-1}}\right)$ & 0.130 & \pm & 0.00504 \\
\hline & & $\mathrm{R}^{2}$ & 0.917 & & \\
\hline
\end{tabular}

